\title{
THE MODERNIZATION OF COMMERCIAL SECURITY UNDER THE UNIFORM COMMERCIAL CODE
}

\author{
HOMER KRIPRE*
}

Article 9 of the proposed Uniform Commercial Code ${ }^{1}$ had as its background substantial bodies of earlier statutory material on security in chattels and receivables, such as the Uniform Conditional Sales Act, ${ }^{2}$ the Uniform Chattel Mortgage Act, ${ }^{3}$ the Uniform Trust Receipts Act, ${ }^{4}$ Factors' Lien Acts, ${ }^{5}$ and conditional sale and chattel mortgage legislation in nearly every state, and "accounts receivable legislation" in the majority of states. ${ }^{6}$ Article 9 is among the most novel of the articles of the Code in the extent to which it represents a complete recasting of the prior statutory material dealing with the same subject matter, with new concepts replacing the old.

Article 9 covers the whole field of security in tangible chattels, thereby replacing the earlier statutory material on such subjects. It also deals with the whole subject of the transfer of "receivables" (choses in action), whether by way of security or by way of transfer of absolute ownership therein, thereby replacing all of the state legislation on that subject adopted in the last ten years.

It will be seen that the article links up very closely with the Articles on Sales and on Commercial Paper (negotiable instruments). A sale of goods, unless it is strictly a cash sale, gives rise to a receivable of some sort. Even if the receivable is an ordinary 30 or 60 day open account, it may itself become a subject of a separate financing transaction. Such financing occurs in large volume when the merchant does not have the working capital with which to cover the lag between the time when he is required to pay for his merchandise and the time when he has sold it and his customer is required to pay for it. Thus arise the fields of "factoring" (which is basically the purchase by a financial institution of open accounts without recourse,

- A.B. r93r, J.D. r933, University of Michigan. Presently Assistant to the General Counsel, C. I. T. Financial Corporation, New York. Formerly Assistant Solicitor, United States Securities and Exchange Commission. Author, Chattel Paper As a Negotiable Specialty Under the Uniform Commercial Code, 59 Yale L. J. 1269 (1950); The "Secured Transactions" Provisions of the Uniform Commercial Code, 35 VA. L. Rivv. 577 (I949), and various other articles in legal periodicals.

1 Unless otherwise indicated, all references herein are to a Reporters' mimeographed draft of Article 9 prepared for working purposes subsequent to the printed September I950 Revisions of Article 9. It is believed that this mimeographed draft, in substantially its present form, with the same section numbering, will appear as the final draft of Article 9 to be presented to the American Law Institute and the National Conference of Commissioners on Uniform State Laws at their May 1951 joint meeting.

$2_{2}$ UnIFORM LAwS ANmotated I. This Act has been adopted in 12 states and territories.

${ }^{3}$ This Act was never adopted by any state.

4 Uniform Laws Annotated 672. This Act has been adopted in 28 states, and the steadily increasing number of states of adoption has shown the usefulness of the Act.

"These laws are not sponsored by the National Conference of Commissioners on Uniform State Laws, but in substantially similar form they have been adopted in 2I states. See, e.g., New York Pers. Prop. LAW $\$ 45 ;$ N. J. Rev. Stat. tit. 2, ch. 60, Art. 20. The statutes are summarized in Silverman, Factoring: Its Legal Aspects and Economic Justification, 13 LAw \& ConTEMP. ProB. 593, 602-603 (1948).

The statutes are classified in Silverman, supra note 5, at 605-606. 
and with the financial institution collecting the accounts) and of "accounts receivable financing" (which is essentially the assignment of open accounts as security for a loan, with the assignor collecting and accounting to the assignee for the proceeds).

If the sale by the merchant deals with durable consumer goods like automobiles or refrigerators, or with industrial machinery or equipment, the credit extended may be for terms running for two to five years and payments in installments may be provided. In such a case the merchant wants to retain security in the goods, and customarily has done so in the forms known as conditional sale or chattel mortgage. Thus the sales problem leads to the problems of chattel security. Moreover, the amounts tied up in these long-term receivables or "chattel paper" may be many times greater than the merchant's inventory or his entire working capital, and he may have to raise cash either by selling or pledging the chattel paper. Thus the sales problem leads naturally into the legal problems connected with the assignment of these longterm receivables.

If the merchant does not have even sufficient working capital to provide for his inventory, he may have to obtain credit from his supplier, or credit from another source with which to pay his supplier. This credit, when it has to run beyond the conventional 30 or 60 days, is frequently supported by security in the goods involved, which security has customarily taken the form of a chattel mortgage on the goods, a trust receipt, more recently a factor's lien, and less frequently a conditional sale of the goods. Thus, the sales problem reaches backward to these forms of tangible security in a merchant's stock in trade, or inventory.

Finally, any of the forms of receivables involved may be evidenced by a negotiable instrument, and in fact conditional sale contracts and chattel mortgages evidencing the sale of goods to a user are frequently accompanied by a negotiable promissory note. Thus, the subjects of sales and of the creation and assignment of chattel paper tie in (or should tie in) with the field of law formerly known as negotiable instruments and known in the Code as Commercial Paper.

\section{False Starts in Codifying Commercial Security}

In attempting the integration and codification of this multifarious subject, or group of subjects, the draftsmen made several false starts.

r. Organization of the Material. The draftsmen in the beginning were overly impressed with the economic fact that inventory flows naturally into receivables and that both inventory and receivables constitute the basic working capital of the merchant. By a series of definitions they, therefore, tried to assimilate receivables into inventory for legal purposes. The resulting drafts ${ }^{7}$ failed to take into account the fact that many of the problems of receivables relate to the assignment thereof, and

\footnotetext{
7 Tentative Draft No. I-Article VI, April 21, 1948; Tentative Draft No. 2-Article VII, Chapter III, August 6, I948; mimeographed draft of Article VII, Chapter III, circulated December 9, I948; May 1949) Draft, Article 7, Part 3 .
} 
that these assignment problems involve three parties: the merchant, the buyer of the goods, and the assignee of the buyer's obligation. Inventory financing, on the other hand, involves only a two-party relationship between the merchant and his creditor. Moreover, there is little homogeneity between the problems of the goods on the self, the $3^{0}$-day unsecured receivable, and the long-term secured installment receivable. The drafts constructed on this basis were wholly unworkable and the draftsmen were commendably quick so to concede.

In order to get a more accurate view of the variations in the problems involved, some drafts were then constructed based on the nature of the subject matter, e.g., pledge, inventory financing, accounts receivable financing, consumer goods, crops, and industrial equipment. These drafts were very helpful in focusing attention on the extent to which these various subject matters had elements in common, and the points at which the subject matters had to be treated separately. ${ }^{8}$ In September, I949, the draftsmen were able to achieve essentially the present structure, based on the following principal topics: rights of the parties to the agreement; rights of third parties, including perfection of security interests; formalities of filing; and rights on default. With this structure the problem of organization of the material has been largely overcome, and it has been possible to view the substantive problems without the hampering effect of the former unsuitable arrangements.

2. Protection of the Debtor. The draftsmen made another false start in conceiving that they could drastically reshape the relative positions of debtor and creditor, and considerably weaken the rights of the creditor vis-a-visis the debtor. The same conception shown in the Sales article and its comments, ${ }^{10}$ that ordinary everyday business is filled with examples of the big fellow oppressing the little fellow, dominated the drafting of remedies in the Secured Transactions provisions. The draftsmen did not, and in the present writer's opinion could not, make any showing that there were significant abuses requiring correction in the general field of commercial secured lending. In the absence of justification, the paternalistic drafts ${ }^{11}$ were wholly unacceptable to any representatives of creditor interests, and most of these provisions have been wisely abandoned. While it has been said that the abandonment of these provisions converted Article 9 into a "creditors' statute," such thinking misconceives the true situation. Users of credit, as well as the creditors, gain advantage from a legal structure which makes possible the extension of credit simply and with certainty as to security. Uncertain legal structures, on the other hand, prejudice debtors with respect to the availability of prospective creditors, the types of creditors willing

\footnotetext{
${ }^{8}$ These drafts were mimeographed for working purposes; were discussed at a conference of the Reporters, their official advisers, and certain other persons in New York in July, 1948; but were never circulated generally.

' Scptember 1949 Revisions of Article on Secured Transactions (then designated Article 8). The structure therein adopted has been basically retained in all later versions.

${ }^{10}$ Proposed Final Draft (Spring 1950) \$2-202, comment $3 ; \$ 2-209$ and comments; $\$ 2-302$ and comments; $§ \mathrm{I}-205$, comment 6 .

11 Tentative Draft No. 2-Article VII, Chapter III, August 6, 1948, $\$ 320$ and comments; mimeographed draft of Article VII, Chapter III, circulated December 9, 1948, $\$ 324,329,329 A$.
} 
to enter the field, and the rates necessary to compensate the creditors for the risks involved. At present, the enforcement remedies in Article 9 are, generally speaking, practical, efficient, and just to both parties. The only vestige of paternalism still remaining in Article 9 is the provision for disclosure on consumer transactions, discussed below.

3. Problems of Security and Problems of Credit. There remain a group of false starts which appear likely to persist as unsatisfactory solutions to certain problems relating to sales to consumers. The draftsmen have assumed that the purported evils involved in the extension of installment credit to consumers derive from the fact that such credit is secured. This is a completely erroneous analysis. The problems of cost in the extension of credit to consumers arise out of the nature of a sale on credit as such, and not out of the security. The same problems exist in the case of sales of goods to consumers on installment credit where there is no security. ${ }^{12} \mathrm{Be}$ cause of the faulty analysis, the disclosure provision with reference to consumers' credit transactions is placed in Article 9, where its applicability is made dependent on the fact that security is taken, rather than in Article 2 on Sales where it should be if its applicability were made co-extensive with the problems. Likewise, the penalty for nondisclosure or inadequate disclosure is made loss of lien, ${ }^{13}$ instead of a penalty more directly related to the problem, namely, the cost of the privilege of receiving credit. ${ }^{14}$ Similarly, the treatment of the use of a negotiable note in connection with such sales (with its concomitant potential cutting off of consumer defenses in the hands of a holder in due course) is placed in Article $9,{ }^{15}$ where its applicability is made dependent upon the existence of security, rather than in Article 2 on Sales or Article 3 on Commercial Paper, where it would have the proper scope and be applicable to all credit sales in which a negotiable note is taken. ${ }^{16}$

\section{II}

\section{Leading Features of the Codification}

With this background, we can discuss the most important features of Article 9 as presently drafted.

I. Chattel Financing as Commerce. We can heartily approve the recognition of chattel financing and receivable financing as fields of commercial law, and their inclusion in a Commercial Code which starts basically with a sale and carries it through the legal ramifications of the chain of events thus begun. The proposed removal of these fields of law out of the atmosphere of property law and into the atmosphere of commercial law is highly desirable, because these types of transactions are vital to commerce in goods and the receivables are themselves important subjects of commerce. ${ }^{17}$

\footnotetext{
${ }^{12}$ This problem is considered at greater length in Kripke, Chattel Paper As a Negotiable Specially Under the Uniform Commercial Code, 59 YALE L. J. I210, 1212-1214 (1950).

$13 \$ 9-209$.

$15 \$ 9-207$.

14 Kripke, supra note 12, at $12 x_{3}$.

${ }^{16}$ See Kripke, stipra note 12, at 1218-1219.

${ }^{17}$ The economic integration of these fields of law with commercial transactions is discussed in Kripke, The "Secured Transactions" Provisions of the Uniform Commercial Code, 35 VA. L. REv. 577, 578-586, 634.615 (1949).
} 
2. Omission of Automobile Title Problems. In contrast with this desirable recognition of chattel security as a field of commerce demanding codification was the decision to omit from the Code a uniform treatment of lien and title problems relating to automobiles. The automobile is one of the largest single objects of commerce in goods. As such, it presents special problems of title and security because of its mobility, its large unit value which requires financing, and its durability which makes possible long-term financing. For the intercity and interstate truck, these problems are intensified. Attempts had been made in the past to deal with the ownership problems of automobiles through the certificate of title device, and one such attempt was made in a uniform act sponsored by the National Conference of Commissioners on Uniform State Laws. ${ }^{18}$ This act and many of the separate state statutes were wholly inadequate to meet the actual commercial problems of automobile financing and ownership. Recognizing the importance of the subject for commerce and the inadequacy of the existing state of the law, the sponsors of the Code set out to insert in their Secured Transactions article a treatment of automobile title and lien problems. ${ }^{19}$ Unfortunately, their attention was turned to this problem too late in the project, and the draft appearing in the first overall compilation of the Code in May, I949 was stated to be only a single Reporter's draft which had not yet been considered by the Chief Reporter and staff or other persons in the hierarchy of the sponsor organizations. ${ }^{20}$ In the September, I949 draft of the Secured Transactions article, this material on motor vehicles was deleted, and the conclusion was orally announced at the September, I949 joint meeting of the sponsor organizations that this subject could not be treated without going too far in the direction of police regulation. The earlier uniform law on the same subject and another uniform law on automobile registration may cause one to doubt the necessity for this conclusion, and certainly it is particularly regrettable that the most important single subject matter of chattel ownership and chattel security is being left with its applicable law in a chaotic state. The single object of commerce which most vitally needed uniform law throughout the country has been excluded from the attempt to achieve uniformity.

Not only has this problem been denied the uniform national treatment which it so badly needs, but the Code has not even given adequate extraterritorial effect to existing certificate of title laws. Section 9-103, in requiring refiling of security interests when chattels have been moved from one state to another, gives no special treatment to a security interest shown on the certificate of title under the law of the state of registration, when the automobile is subsequently brought into another state. $^{21}$

3. Place of Filing of Chattel Liens. It is also regrettable that the draftsmen's

${ }^{18}$ Uniform Motor Vehicle Anti-Theft Act, II UNIForm Laws ANNotated 143.

${ }^{10}$ Article 7, Part 8, of the May 1949 Draft. ${ }^{20}$ May 1949 Draft, page 69r, footnote.

${ }_{21}$ In a conference with spokesmen for American Bar Association committees, some of the Reporters indicated recognition of the need for special treatment of certificate of title situations, in the event of removal of the chattel. The draft which next appeared, however, does not treat the problem separately 
recognition of chattel security problems as commercial problems should be compromised by concessions of expediency toward local property law conceptions. The Code is necessarily a compromise of the views of all parties concerned, including the general membership of the American Law Institute and the National Conference of Commissioners on Uniform State Laws. On the problems of filing security interests, the joint meetings of these sponsor organizations have shown an insularity of approach. Apparently, the security interests are not thought of as incidents in the nationwide mechanism of the distribution of goods. Instead, they are thought of as local property law transactions, in which the local legal practitioner should be able to search a title in the county records. As a result, every draft of the Reporters providing for state-wide filing of chattel security interests has met with opposition from the floor of the sponsor organizations. The latest current draft still contemplates local filing as well as state-wide filing, for debtors whose places of business are in a single county, in the case of receivables, inventory, and industrial equipment. The fact that the provision for county filing has been printed in brackets in the last several drafts ${ }^{22}$ indicates that the Reporters still hope to win their point on the floor, and one may join them in this hope. The Reporters, however, have given up the struggle in the case of consumer and farm goods and have called for local filing. ${ }^{23}$ Since this provision applies almost exclusively to automobiles and farm tractors, ${ }^{24}$ its inadequacy to meet the facts of modern mobility is evident.

4. The Filing of Consumer Liens. The Reporters have also been faced with traditionalism in the consideration of a rule as to the filing of security interests in consumer goods. Generally speaking, existing chattel mortgage laws require filing of all chattel mortgages regardless of the type of commodity or amount involved. Similarly, where filing is required for conditional sale contracts, the filing requirement does not depend on the nature of the goods or the amount involved; and where filing is not required, the rule of law applies uniformly.

A strong case could be made that this uniform treatment is obsolete. Under modern conditions, particularly in urban areas, the filing records are almost never consulted in connection with liens on consumer goods. The filing, therefore, gives no actual notice, and it can be argued that the validity of the lien against third parties should not be made to depend on compliance with a filing requirement. Some of the Reporters have at various times indicated sympathy with this position, but any attempt to omit a requirement for filing of consumer goods liens always runs into opposition on the floor of the sponsor organizations. The current draft of Article 9 omits a filing requirement in the case of purchase money security interests in consumer goods (other than fixtures, motor vehicles, and farm equipment having a purchase price not in excess of $\$ 2500) .^{25}$ In other cases, filing is required for security interests in consumer goods. It may be conjectured that these provisions represent the Reporters' attempt to compromise between the theory that filing is

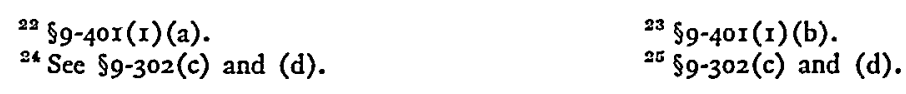


meaningless for consumer liens, and the insistence of the general membership of the sponsor organizations that there be filing in all cases on chattel liens.

Unless one is willing to say that the largest exemption from filing requirements that is attainable under the political realities of the sponsor organizations is per se desirable, the present provisions seems to be an illogical solution of the problem. Once a security interest has been created, a third person does not care whether that interest was created in a purchase money transaction or in a loan transaction. If he can search the files to ascertain the existence of a security interest for loan transactions, he should be satisfied upon completion of his search that he has discovered all prior security interests which are good against him. In such cases there should be no unfiled interests which he cannot find by searching, but which are valid against him. On the other hand, if we accept the premise that the records will seldom be searched, then there is no more reason for requiring the filing in the case of loan transactions then there is in the case of purchase money transactions. The dis. tinction in rule is further complicated by the complexity of the "purchase money" concept, whose definition in the Code is by no means self-evident. ${ }^{26}$ A company in the small loan business might find that its loan was or was not a purchase money security interest, and, therefore, did or did not require filing for its perfection, entirely without reference to any set of facts of which the lender was cognizant.

Moreover, the effect of the no-filing rule for purchase money security interests in consumer goods seems to have been an unresolved matter among the members of the reporting staff until very recently. Section 9-307(2), as it existed in the September I950 Revisions, provided (so far as is now material) that a security interest is good against a buyer with notice, including filed notice. The question was raised as to the relationship of this provision to the absence of a filing requirement for purchasemoney interests in consumer goods. It is not clear that the reporting staff as a group conceded that such security interests were good against innocent buyers, which is the normal result when liens or transfers of ownership are valid without filing. At various times members of the reporting staff have argued that there should be no way to protect security interests in consumer goods against a good faith buyer of the goods. If the staff's intention in the September I950 draft was to express the latter position, then surely the result would have been anomalous. It would have put the seller's purchase-money interest in consumer goods at a disadvantage against security interests arising from loans, and would have subjected the seller's interests to defeat at the hands of innocent purchasers. ${ }^{27}$ But surely the general membership

${ }^{20} 99-107$. The definition includes not only a security interest retained by a seller, but also that taken by a lender for the purpose of enabling the debtor to require rights in the collateral, if the money is so used; and even security taken by a person for the purpose of enabling the debtor to acquire an interest in the collateral if the collateral is in fact acquired within ro days, even though the loan is not used to pay the price.

${ }^{27}$ Fortunately, since the 1950 amendment to section 6oa of the Bankruptcy Act (Pub. L. No. $46 \mathrm{r}$, 8Ist Cong.) the "bona fide purchaser" test has been abolished as a test of preference in bankruptcy, except for real estate transfers. See Kupfer, The Recent Amendment to the Preference Section of the Bankruptcy Act, 22 N. Y. St. Bar Ass's Bull. 329 (1950). Cf. Conwill and Ellis, Much Ado About Nothing: The Real Effect of Amended 6o(a) on Accounts Receivable Financing, 64 Harv. L. Rev. 62 (I950). 
of the sponsor organizations in demanding a filing provision intended to provide a mutual means of protection for the holders of the security interest and for third persons, and they would not knowingly agree to non-filing in certain areas if the result would be denial to the holder of the security interest of any opportunity to protect himself. The confused state of the drafting and of its intended effect existed because of the draftsmen's concern with the protection of the buyer of second-hand goods who does not, they believe, search the records before buying from another consumer. But the number of cases of such sales where the first consumer conceals from the second the existence of a lien is infinitesimal, and no problem exists justifying so radical a step as a denial to the holder of a security interest of any means of perfecting his lien against all third parties.28

In the latest version, the ambiguity has been clarified through a rough and ready solution. ${ }^{29}$ The innocent buyer of consumer goods takes free of security interests that are more than one year old, and subject to security interests not over one year old. In practical effect, this means that the buyer is protected against a deception in a small amount but not against a deception in a big amount. The best thing to be said for the solution is that the practical problem is not large in any event, and this solution possibly hits upon an approximate dividing line between situations in which a lay buyer might and situations in which he might not be alert enough to ask about encumbrances.

5. Inventory Financing. The Code materially improves the legal position of inventory financing. At this mature stage in our economic history, when "inventory" includes such items as machinery, automobiles, and other "hard goods," it is possible to think of inventory financing free from the overtones of fraud and concealment with which such financing became associated when the inventory lien transaction was typically a chattel mortgage on a small retailer's stock of groceries or clothing, made with the intent either to defraud creditors or secretly to prefer the mortgagee. Therefore, Article 9 avoids the artificial limitations which appeared in the Uniform Trust Receipts Act concerning the nature and purpose of a trust receipts transaction, which limitations undoubtedly arose as the draftsmen tried to justify to themselves and to others the creation of a form of security without the handicaps of the law of chattel mortgages on inventory. The inventory security device under the Code will not be burdened with "trust receipts" questions as to whether title flows from a prior owner to the "entruster" or whether it comes from the trustee; whether it is a purchase money transaction or a loan transaction; the purpose of the arrangement; or the other limitations of the Uniform Trust Receipts Act. There need be only one single legal form for all of the types of inventory financing which have been carried on through the devices of chattel mortgage, trust receipt, factor's lien, and conditional sale for resale.

\footnotetext{
${ }^{28}$ It may be argued that if the problem is so infinitesimal, professional secured lenders should have no objection to taking the risk of loss of their security interest in favor of bona fide consumer purchascrs. The answer is that no one can foresee the extent to which advantage can be taken of loopholes in the law, once those loopholes are created.

${ }^{29} \$ 9-307(2)$.
} 
In the redrafting there has been an attempt at clarification of the "proceeds" provisions of the Uniform Trust Receipts Act. ${ }^{30}$ There has likewise been a clarification designed to prevent a monopolization of "retail" chattel paper by the secured lender who was providing inventory financing for the inventory out of which the chattel paper arose. ${ }^{31}$ Finally, there has been a clarification of the question of precedence between the inventory-secured person who first files and the inventory-secured person who first makes advances on inventory. The clarification is in favor of the one who first files, ${ }^{32}$ thereby overruling the one case on the subject. ${ }^{33}$

6. Notice Filing in Accounts Receivable Financing. In the field of accounts receivable financing, the Code resolves, in favor of central notice filing, the controversy which has raged before the state legislatures as to the merits of "validation," "filing," and "book marking" statutes. ${ }^{34}$ It is certain that this conclusion will provoke widespread opposition in the important commercial states which have reached a contrary determination of policy in the legislatures and by judicial decision, and it may be doubted whether the other advantageous features of the Code should have been jeopardized by attempting to enforce uniformity on so controversial a subject.

7. Chattel Paper as a Specialty. Among the most highly advantageous features of this article of the Code is the recognition of chattel paper as a specialty, ${ }^{35}$ coupled with the provision that a security interest or other assignment of chattel paper may be perfected by delivery thereof, ${ }^{36}$ or by notation on the paper itself that it has been assigned, ${ }^{37}$ or may be perfected against anyone but a bona fide purchaser by central notice filing. ${ }^{38}$ This recognition will clarify the legal position of a type of receivable which has become an important object of commerce, and facilitate financial dealings therein.

8. Chattel Paper with Negotiable Instruments. The draftsmen have seemingly done no fundamental thinking on the question of the relation between chattel paper and a negotiable note used with the paper. In the early development of the legal machinery for credit sales on installment terms, the third party financial institution was concerned not only with the regular credit hazards involved in the question whether the purchaser would be able to pay, but also in the hazards involved in the purchaser's possible refusal to pay because of dissatisfaction with the merchandise, or fraud or misrepresentation on the part of the seller. Accordingly, as this new type of installment obligations became an important subject of finance, the necessary legal development was facilitated by resort to a negotiable instrument. These instruments had been developed several centuries earlier to meet similar problems involved

30 \$9-306; compare Uniform Trust Receipts Act, \$10.

31 \$9-308; compare Uniform Trust Receipts Act, \$9.I (a).

32 89-3I2.

${ }^{33}$ Donn v. Auto Dealers Inv. Co., 385 Ill. 211,52 N. E.2d 695 (1944).

${ }^{36}$ See Kupfer, Progress in the Amendment of Section 6oa of the Bankruptcy Act, 13 Law \& ConTEMr. Prob. 624 (1948); Pemberton, Notice Filing for Assignments of Accounts Receivable, 13 LAW \& Contemp. Prob. 643 (1948).

${ }^{30}$ \$9-105(b).

${ }^{37} \$ \$ 9-304(\mathrm{r})(\mathrm{c}) ; 9-308$.

${ }^{38} \$ 99-302 ; 9-304(\mathrm{I})(\mathrm{b}) ; 9-308$. 
in the free transfer of business obligations, when the primitive facilities of finance, commerce, and communication resulted in substantial risks to assignees of such obligations. The law merchant developed the concept of negotiability to free third parties from the danger of assertion of defenses to definite obligations set forth in a specified manner, and this concept was by a quite natural development extended to the new types of installment instruments which arose in the course of chattel financing. Although these instruments contained monetary promises which had the definiteness as to the amount and time of payment which is the essence of a negotiable instrument, they were apparently not negotiable because the instruments ordinarily also contained covenants about insurance, care of the property, etc. To get the benefit of negotiability, it became the practice to use a separate negotiable note with, and duplicating the promise to pay in, the security instrument.

Once the legal rights flowing from a transaction become expressed in a negotiable instrument and also in a separate lien instrument with a duplicate promise to pay, all kinds of difficulties can and do arise. Fraudulent double financing, or transfers of the notes without the security instruments and in ignorance of their existence or nature, become possible. Uncertainty arises as to whether the rights of a third party assignee and endorsee are governed by the law of negotiable instruments, or by the law of assignments of non-negotiable choses in action. The obvious answer to the problem at this late date is to create rules of law which would make unnecessary the retention of the two-instrument device, and the obvious way to do so is to change those features of negotiable instruments law which deny negotiability to promises to pay money if accompanied with covenants concerning preservation of the collateral. On the occasion of the adoption of so far-reaching a Code, which includes other substantial modifications of negotiable instruments law, it is particularly unfortunate that the draftsmen did not grapple with the problem. ${ }^{30}$

9. Protection of the Consumer against the Holder in Due Course. Doing nothing to avoid the formal problem of two instruments, the draftsmen have attempted, without complete success, to grapple with the substantive problems involved in the use of negotiable instruments to express obligations arising in credit sales. The solution has been to give negotiable instruments their normal effect when they arise out of sales of commercial and industrial equipment, while denying them their normal effect if created in a consumer goods transaction. ${ }^{40}$ In so doing, the draftsmen have, of course, created inconsistency with their own rules in Article 3 on Commercial Paper as to the status of negotiable instruments, and inconsistency with their own treatment of chattel paper not accompanied by negotiable instruments. ${ }^{41}$

The draftsmen's result as to consumer goods seems merely to have left the law in the state in which it is today: (a) If the holder sues on his negotiable note, he may cut off the defenses of the consumer; therefore, so long as the consumer is able to pay, the Code does nothing to give him the protection to which it is assumed he is

\footnotetext{
${ }^{38}$ This point of view is more fully expressed in Kripke, supra note 12, at 1222-1227.

10 59-207.

$\$ 1$ See Kripke, stupra note 12 , at 1214-1222.
} 
entitled. (b) If, however, the consumer is unable to pay and the holder resorts to the security, the consumer may set up any defenses that are available. However, it is hard to think of defenses which would entitle the consumer to keep the goods without paying for them, so it is rarely indeed that the Code accomplishes anything for the consumer. We may be grateful that the loss of this opportunity for fundamental rethinking of the problem is not as serious as it might be, for the reason that the problem itself is of constantly diminishing importance. As standardization occurs in consumer goods fields, the cases of really justified consumer complaint against the seller have become infinitesimal.

Io. Overruling of Benedict v. Ratner. Since the very early drafts, the Code has contained an interesting provision abolishing the rule of Benedict $v$. Ratner. ${ }^{43}$ This rule is applicable to types of security which are rapidly converted into cash by sale or collection, such as inventory and receivables. The rule states in substance that if the lender does not exercise suitable "dominion" over the cash resulting from the liquidation of the inventory or collection of the receivables, his conduct is inconsistent with the concept of lien and results in the invalidation of the lien. "While in most courts the rule has been given a reasonable application, some of the dicta in the federal courts of the Second Circuit have been most alarming ${ }^{44}$ and have led to extended discussion among lawyers as to the actual and symbolic steps which the lender must take to exert dominion.

There was for a considerable period of time no serious objection to the proposed abolition of the rule of law involved, for it was assumed correctly that the abolition of the principle of law did not preclude the lender from adopting any steps which he deemed practically necessary for the preservation of his security position. More recently, however, lawyers interested in commercial financing have begun to express concern as to the effect of this proposed change of rule, for two reasons.

(a) First, the abolition of any legal requirement of policing the security makes it practicable for a lender to attempt to obtain security in inventory or receivables by inserting a "boiler-plate" clause to that effect in any form of loan instrument, such as a real estate mortgage, bank loan agreement or unsecured loan agreement, and even in such instruments as leases. This opportunity is facilitated by the fact that the Code recognizes the validity of after-acquired property clauses for both inventory security and receivables, ${ }^{45}$ with the result that a provision assigning such security would be effective even though the creditor did absolutely nothing to obtain periodic assignments as the particular items of inventory or receivables in existence

\footnotetext{
"Some courts, with shaky legal reasoning, have found a way to protect the consumer by denying that the note is negotiable or that the holder is a holder in due course. See Kripke, supra note I2, at 12r9-1221. The draftsmen have indicated approval of this line of cases, and at one point the proposed draft codified this approach. Proposed Final Draft (Spring 1950) $\$ 9-209$, and comment 5 thereto. They have now abandoned this approach and gone back essentially to a restatement of the common law. If there really is a situation which requires protection, therefore, the remedy will not be found in the Code, but is left to whatever continuing judicial erosion may occur in traditional concepts of negotiable instruments law.

${ }^{4} 268$ U. S. 353 (I925).

* See Kripke, supra, note 17 , at $589-592$.
}

${ }^{45} \$ \$ 9-108(2) ; 9-203$. 
changed in the normal course of business. A debtor who was careless, poorly advised, or in a weak bargaining position might subsequently find himself with his inventory or receivables unavailable as security, or disregarded as encumbered by persons scrutinizing his financial statements, although the debtor had had no intention of using them as security in the first transaction. Whether under the Code this difficulty would eventually work itself out as lawyers and borrowers became aware of the problem, and whether the lenders who had obtained the purported security would voluntarily release it to make inventory and receivables available to the debtor for future financing, cannot be foretold in advance of adoption of the Code and some experience under it.

(b) The second objection by those interested in commercial financing was that the abolition of the legal sanction for proper administration of collateral would ultimately lead to a most unfortunate competition for business among lenders, upon the basis of a competitive debasement of proper collateral control practices. Inventory financing and receivables financing are peculiarly susceptible to the risk of disappearance of the collateral, and accounts receivable financing in many contexts is likewise peculiarly susceptible to fraud unless carefully administered. Any competitive pressure against the safeguards which have been developed for this business would be most unsound.

In opposition to both of these objections, it may be pointed out that provisions abolishing or limiting Benedict v. Ratner already appear, although not so drastically phrased, in the accounts receivable statutes of a few of the states. ${ }^{40}$ While experience under these state statutes has not yet been sufficient to justify a firm conclusion, it must be said that the dangers above mentioned have not yet significantly appeared in the experience of the states involved. Nevertheless, there is very real concern on these subjects on the part of many students of the Code.

Ir. Revolving Security and Bankruptcy Preference. A further very well-intended provision of the Code is the attempt to write a provision which would protect a creditor against preference where his security increased in the normal course of business within four months of bankruptcy. ${ }^{47}$ Many financing arrangements contemplate what is in effect a continuing loan secured by a constantly changing aggregate of inventory or receivables. Most such arrangements contemplate that the loan will be secured by all of the debtor's inventory or all of his receivables, or all of a type or types of inventory or receivables. The quantity of such collateral will necessarily change in the ordinary course of business, and an increase will not necessarily be accompanied by a simultaneous increase in the amount of the loan. Yet if an increase in collateral occurred within four months of bankruptcy and at a time when (in the opinion of the court) the creditor knew that the debtor was insolvent, the increase in collateral might be held to be a preference. The draft attempts to pre-

\footnotetext{
${ }^{40}$ See e.g., Colo. Stat. Ann. c. I2A $\$ 5$ (Cum. Supp. I947); Conn. Gen. Stat. \$1276i(d) (Supp. 1947); Mrch. Stat. Ann. \$19.846 (Cum. Supp. I947); N. C. Gen. Stat. Ann. \$\$44-83 (Cum. Supp. 1947); Wash. Rev. Stat. ANN. \$272I-8 (Supp. 1947).

"\$9-108(2).
} 
clude this result by providing that where value is given under an arrangement containing an after-acquired property clause, the after-acquired property "is not security for a pre-existing debt or claim" if the debtor acquires such collateral either in the ordinary course of business or pursuant to a contract of purchase made within a reasonable time after the making of the security agreement and pursuant thereto. In so far as this provision attempts to change an uncomfortable fact by asserting the contrary, the draftsmanship is unfortunate. Assuming that the intent is to state that the uncomfortable fact shall not have its ordinary legal consequences, it may be questioned whether any state legislation can affect the definition of preference in the Bankruptcy Act. At any rate, the point has been a troublesome one and the effort to solve it is all to the good.

12. Disclosure to the Consumer. As of this writing Article 9 still contains Section 9-209, which is a provision requiring disclosure to the consumer of the computation of the amount of his obligation. Statutes of similar nature have been passed in many of the states, but many of the statutes go much further. Some include regulation of finance rates, prepayment privileges, and delinquency penalties. Some of the statutes provide licenses for time sellers and finance companies, and administrative machinery for the supervision of the situation. Some of the statutes are limited to automobile transactions, or contain specific provisions with respect to such transactions and the insurance complications that go with automobile financing. There are also in many states detailed regulations of the business of making small loans.

The draftsmen have chosen to enter this field by confining themselves only to disclosure. Thus far, they have not succeeded in drafting a disclosure provision which is deemed practicable by those with most experience in the field of financing installment sales. In that field, where the instruments are originated by thousands of sellers and their salesmen who have no legal training, and where the individual amounts of transactions are small, simplicity and operating efficiency are absolutely essential, and those interested in the field are not yet satisfied that the draftsmen have achieved either.

No explanation has yet been offered in any of the printed comments on the Code for the draftsmen's conclusion that they should enter this field, instead of leaving it for separate determination in the several states, where proposals covering the wide range of possible treatments of the subject are regularly offered at each year's legislative sessions. At one of the joint meetings of the sponsor organizations, one of the draftsmen stated that they desired to treat the subject to prevent any inference that they did not feel that consumer protection was necessary. However, no such inference could possibly be drawn from a code which does not purport elsewhere to cover comprehensively the problems of legal protection of the consumer. On the contrary, the draftsmen have run the risk of an inference that their provision is the only treatment of the subject which the sponsor organizations think necessary. They have entered a controversial field under the handicap that they could not deal 
adequately with the substantive problems involved and were not free to provide for administrative regulation if that were deemed necessary.

In the long run the safest thing to do with Section 9-209 will be to eliminate it. This is not to contend that no legislation in the field of consumer credit is necessary. Such legislation is being offered before all of the legislatures constantly, and the suggestion is merely that each state be permitted to deal with the problem in its own way. The Code could not in any event accomplish uniformity, because it is expressly contemplated that the Code will not replace the varied existing legislation in the field. ${ }^{48}$

\section{ConcLusion}

On the whole, Article 9 of the Code is an improvement over existing law. There is little in it to which one must affirmatively object. ${ }^{49}$ Its largest defects are those of omission: failure to deal adequately with problems which cryingly needed attention, such as the automobile certificate of title problem. On the other hand, there is much in it to which one can give hearty affirmative approval, such as the strengthening of the legal basis for inventory financing, and the clarification of the status of chattel paper.

${ }^{48}$ See notes to $\$ \$ 9-204$ and 9-209.

${ }^{20}$ Many people will except from this statement the provision requiring filing of notice of assignment of accounts receivable. Moreover, as of this writing the draft referred to in note I, supra, contains some technical difficulties of draftsmanship which must be resolved. 